\title{
Aligning employee service recovery performance with brand values: the role of brand- specific leadership
}

Dr Khanyapuss Punjaisri ${ }^{1}$

Hull University Business School,

University of Hull,

Hull, HU6 7RX

e-mail: k.punjaisri@hull.ac.uk

tel: $(+44) 1482-46-192$

fax: $(+44) 148-46-3484$

Dr Khanyapuss Punjaisri is lecturer in Marketing at Hull University Business School, University of Hull, UK. She is a PhD graduate from University of Strathclyde. Her research interest is in services marketing, corporate branding, and internal brand-building. She has publications in different journals, namely European Journal of Marketing and Journal of Service Management.

Professor Heiner Evanschitzky

Aston Business School, Aston University, Birmingham, B4 7ET

e-mail: h.evanschitzky@aston.ac.uk tel: $(+44) 121-204-3113$

Dr Heiner Evanschitzky is Professor and Chair of Marketing at Aston University, UK and Visiting Professor at University of St. Gallen, Switzerland. Heiner received his $\mathrm{PhD}$ and his

\footnotetext{
${ }^{1}$ Corresponding author
} 
Habilitation from the University of Muenster, Germany, and worked there as Assistant and Associate Professor. His research investigates interesting and relevant problems with an attempt to develop impactful conclusions. The current focus primarily lies in Service and Retail Marketing/Management where he focuses on issues around the Service Profit Chain concept. These include the areas of customer (value) management, franchising, myopic marketing management, research on satisfaction and loyalty, sales management, and relationship marketing. His work has been published in journals such as Journal of Marketing, Journal of Retailing, Journal of the Academy of Marketing Science, Journal of Service Research, and Journal of Product Innovation Management.

\section{Dr John Rudd}

Aston Business School, Aston University, Birmingham, B4 7ET

e-mail: j.m.rudd@aston.ac.uk

tel: $(+44) 121-204-3218$

Dr Rudd is a Senior Lecturer and Head of the Marketing Group at Aston University, UK. His research interests are strategic in orientation, and examine issues of sales and marketing strategy, strategic decision making, stakeholder relationships and the performance impact of marketing capabilities and resources. His work has been published in journals such as Journal of Marketing Management, Journal of Business Research and Journal of Strategic Marketing. 


\title{
Exploring trust-based management in the service recovery context: the employees' perspectives
}

\begin{abstract}
This paper presents, and empirically tests a conceptual model of relationships between brandspecific transformational and transactional leadership, trust in leader and in corporate brand, brand identification, and service recovery performance from employees' perspectives. Results from a study of 246 customer-contact employees show that brand-specific transformational leadership has a positive impact on all variables studied, while brandspecific transactional leadership is ineffective in fostering brand-supportive behaviours. More specifically, brand-specific transformational leadership's effects on employees' service recovery performance are mediated by trust in the leader, trust in the corporate brand, and employees' brand identification. Implications and directions for future research are discussed.
\end{abstract}

\section{Summary statement of contribution}

This study is the first to assess how brand-specific leadership can influence employees to perform successful service recovery, aligned with its brand promise. By incorporating leadership theory and social identity theory, we extend existing theory development regarding employees' service recovery performance. Trust is the crucial concept that ties the proposed framework. The study suggests that leadership's effects on service recovery performance are mediated by trust and brand identification of employees.

\section{Keywords:}

Leadership, trust, identification, service recovery, structural equation modelling 


\section{Introduction}

In recent years, researchers have paid particular attention to brand orientation. Brand orientation is the inside-out approach that seeks to protect brand identity through an internal understanding of core brand values central to brand identity (Urde, 1999). A brand-oriented organisation is able to generate and sustain a shared sense of what it stands for, to create superior value for stakeholders, and ultimately superior organisational performance (Ewing \& Napoli, 2005).

Baumgarth (2010) argues that brand orientation includes values, norms, artefacts, and behaviours. Brand values reflect basic understanding of the brand, which are interpreted by employees and become norms, or rules that guide employee behaviour during interactions with external stakeholders. This highlights the role of employees as key deliverers of brand values.

When the company is the primary brand, as the case for service organisations (Berry, 2000; Berry \& Lampo, 2004), the perspective changes from the product or service as the brand to a more holistic corporate view (Morsing \& Kristensen, 2001), referred to as the corporate brand. In services settings employees are considered synonymous with the brand by customers and other external stakeholders (Berry, Lefkowith, \& Clark, 1988). As such, the important task of managing employees to reinforce brand values becomes an important and persistent challenge for leaders.

Managing employee behaviour is a key task for leaders. Therefore, within the branding literature, leadership at top management- and line manager-levels has been considered a crucial antecedent of employees' brand-supporting behaviours (e.g. Miles \& Mangold, 2004; Wieseke, Ahearne, Lam, \& van Dick, 2009). While top management set the tone and vision for the corporate brand (Vallaster \& de Chernatony, 2005), it is line managers who are proximal to employees, and thus have a critical role in filtering, interpreting, and enacting 
visions and values for employees (Ruiz, Ruiz, \& Martinez, 2011). Therefore, line managers are the key agents through which senior management influence employees' behaviours and attitudes (Mayer, Kuenzi, Greenbaum, Bardes, \& Salvador 2009). The term 'leader' ('leadership') in this study is treated as synonymously with 'line manager' ('leadership through line manager').

Due to the characteristics of services, such as heterogeneity and simultaneity, service brands are often challenged with service recovery, as a result of service failures. Little theory development has occurred regarding the influence of leadership on employees' performance in service recovery. This is at odds with literature that suggests that service recovery can restore customers' satisfaction levels, and is an important factor in overall company performance (e.g. De Matos, Henrique, \& Rossi, 2007; Evanschitzky, Brock, \& Blut, 2011; Magnini, Ford, Markowski, \& Honeycutt, 2007).

When service failure happens, employees are required to act in a timely manner, to resolve customer problems. Due to the pressure to respond, employees may be unable to consult leaders for guidance on specific actions and rely on shared understanding of brand values. Therefore, without effective leadership to ensure shared understanding of brand values, employee service recovery performance may deviate from the expectations or aspirations of the corporate brand.

A key mechanism, through which effective leadership is translated into brand-supporting behaviour, is employee trust. Research differentiates between employees' trust in the leader and trust in the corporate brand (e.g. Colquitt, Conlon, Wesson, Porter, \& Ng, 2001; Dirks \& Ferrin, 2002), and shows that trust leads to brand identification (van Knippenberg \& Sleebos, 2006). Despite the importance of employees in service delivery, the services marketing literature has not sufficiently explored trust from an employees' perspective. Since employees' attitudes and behaviours influence customers' perceptions and experiences of the 
brand (Schneider \& Bowen, 1985), it is of significant importance to assess the role of trust and identification in mediating the impact of leadership on the service recovery performance of employees.

The proposed conceptual framework that underpins this study, integrates the role of leadership, employee trust and identification, and brand-supporting behaviour. It draws on literature from leadership theory, social identity theory, and empirical studies of trust. More specifically, this study investigates how two fundamental approaches to leadership, transactional leadership (TRL) and transformational leadership (TFL) (Bass, 1985), mediated through two facets of employee trust and brand identification influence employees' service recovery performance.

The remainder of the paper is organized as follows. First, the extant literature is discussed and key terms are introduced. Based largely on leadership and social identity theory, a conceptual model is developed. Using data from 246 customer-contact employees of a bank, we uncover the key role of brand-specific transformational leadership in influencing service recovery performance, mediated by employee trust and identification. Finally, theoretical and managerial implications are discussed, and opportunities for further research in this important area are presented.

\section{Literature overview}

Before deriving hypotheses, we discuss the current state of the literature and provide definitions of the key terms of the model.

Employees’ service recovery performance (SRP)

Service recovery performance is defined as the performance of a service employee who directly handles customer complaints in rectifying the deviation and/or recovering customer satisfaction after service failures (Liao, 2007). Based on Boshoff \& Allen (2000), service 
recovery in this study focuses on employees' perception of their performance in recovering customers who have experienced a service failure (Liao, 2007; Motowidlo, 2003). This definition is argued to place service recovery performance in the realm of job performance (Boshoff \& Allen, 2000); this is in line with Lin (2011) who argues that service recovery performance should be part of overall employee performance.

Customer-contact employees are directly responsible for the delivery of services, and influence how customers experience the corporate brand and core brand values (e.g. Heskett, Sasser, \& Schlesinger, 1997; Schneider, Ehrhart, Mayer, \& Saltz, 2005). However, in service recovery, while customer-contact employees that deal with customer complaints may not directly be accountable for service failures, they have a key role to enact service recovery activities (Sparks \& McColl-Kennedy, 2001). Hence, employee performance during service recovery impacts on how customers evaluate the corporate brand.

Hart, Heskett \& Sasser (1990) contend that while identifying a service problem quickly is essential, employees have to act fast for service recovery to be effective. Therefore, in a brand-oriented firm, leaders seek to provide conditions within which employees perceive service recovery as an integral part of service delivery; and do so in ways that are aligned with brand values that encompass brand identity.

Empirical studies in this area present a number of employee service recovery actions such as acknowledgement, explanation, apology, urgent reinstatement, management intervention, empathy, symbolic atonement, compensation, discounts, replacement, refund, and follow-up (Bell \& Zemke, 1987; Boshoff, 1997; Johnston, 1995; Kelley, Hoffman, \& Davis, 1993). Johnston \& Fern (1999) posit that use of these actions should be appropriate to customers' perceived service failure, suggesting service recovery behaviours are context-specific. 
As mentioned earlier in this section, employee service recovery performance is influenced by leadership. Therefore, we next discuss two distinct types of brand-specific leadership, transactional leadership (TRL) and transformational leadership (TFL).

Brand-specific TRL and TFL

Based on the leader characteristics of TRL and TFL (Bass, 1985; Podsakoff, MacKenzie, Moorman, \& Fetter, 1990), brand-specific TFL is defined as 'a leader's approach to motivating his or her followers to act on behalf of the corporate brand by appealing to their values and personal convictions' (Morhart et al., 2009: 123). Here, we adopt Morhart et al.'s definition that brand-specific TFL will act as a) a role model in living the brand, b) articulate a compelling and unique brand vision that will arouse personal involvement and pride in the corporate brand, c) inspire followers to represent brand values in work situations, including service recovery and d) teach and coach followers to grow into job roles as brand representatives.

In contrast, brand-specific TRL is defined as a leader's approach to motivating followers to act on behalf of the corporate brand through contingency rewards (Morhart et al. 2009). We argue that brand-specific TRL would possess such characteristics as a) specifying behavioural standards as brand representatives for all situations and specifying rewards when role expectations are met, and b) clarifying what constitutes ineffective performance, and punishing employees for not being aligned with brand standards set by core brand values.

As brand-specific leadership is identified in the literature as a source of motivation that dives brand-supporting behaviours (Morhart et al. 2009), our study examines the mechanism by which brand-specific leadership affects employees' service recovery performance, aligned with the corporate brand.

The conceptual framework derived in the next section, integrates several streams of literature i.e. leadership (TRL/TFL) theory, trust, social identity theory, and service branding 
(service recovery). Figure 1 provides an overview of relevant theories and connections used to develop the conceptual model presented in Figure 2. 
Figure 1: Overview of relevant theories and connections

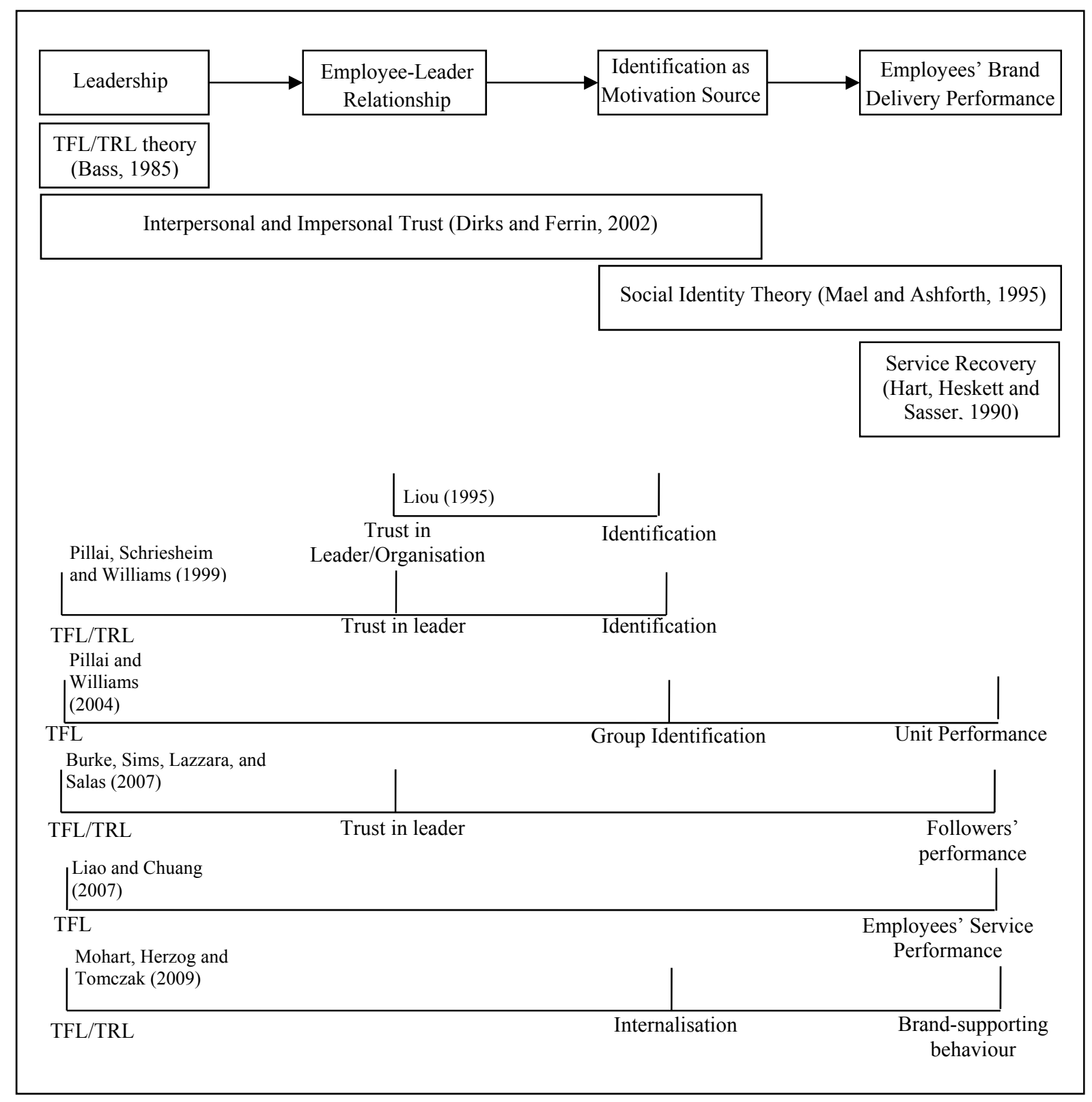




\section{Conceptual model and hypotheses}

Authors in the services branding literature highlight the importance of employees, particularly those that interface directly with customers. Similarly, brand orientation literature underlines the important role of employees in protecting brand identity. This places an emphasis on the leaders, whose behaviours affect employees' understanding of brand values encapsulated by brand identity (Urde, 1999).

Existing studies focus on overall employee performance of service delivery, but do not examine service recovery performance; although it is argued to be part of their role and inevitable and complex in nature (Hart et al., 1990). Often, service recovery requires spontaneous and impromptu actions from employees (e Cunha, Rego, \& Kamoche, 2009), hence leaders should ensure that spontaneous and impromptu actions from employees are aligned with brand values and brand identity. This study assesses brand-specific leadership within the context of service recovery.

Brand-specific leaderships and employees' trust

Brand-specific TFL is one of the antecedents of trust in an organisation setting, promoting trust between members and leaders, and between employees' and the organisation (e.g. Dirks \& Ferrin, 2002). Indeed, Atkinson \& Butcher (2003) indicate that trust exists at the impersonal (corporate brand) level, and the inter-personal (leader) level. Other studies argue that employees distinguish between the impersonal and interpersonal levels when making assessments (e.g. Colquitt, Conlon, Wesson, Porter, \& Ng, 2001) regarding relationships with leaders and the corporate brand.

Studies have documented the effect of TFL on trust. For example, Brower, Schoorman, \& Tan (2000) argue that TFL is founded on a social-exchange relationship that provides a basis for trust to grow. Burke, Sims, Lazzara, \& Salas (2007) posit that TFL has strong predictive power explaining employee trust in leader. TFL behaviours such as role-modelling (Rich, 
1997), inspiring followers to involve with the corporate brand, charismatic ways to influence followers' emotional identification (e.g. Jung \& Avolio, 2000; Dirks \& Ferren, 2000) and value articulation (Gillespie \& Mann, 2004), have been found to have a significant impact on trust in leader. Hence, as effectiveness of leadership should be task-specific (Mullen \& Kelloway, 2009), the following hypothesis is proposed:

H1: Brand-specific TFL positively influences trust in (a) leader and (b) corporate brand.

Due to an emphasis on contingent rewards and punishment, brand-specific TRL causes employees to perceive their relationship with the corporate brand as an outcome of an economic exchange contract. While Pillai, Schriesheim, \& Williams (1999) find no relationship between TRL and employee trust in organisation and leader, other studies (e.g. Gillespie \& Mann, 2004; Shamir, 1995) found a positive relationship between TRL and employee trust. Studies finding positive relationships, argue that because brand-specific TRL consistently fulfils contingent rewards and punishments, employees perceive that they are recognised and rewarded fairly and as such develop trust in their leader (Bass, Avolio, Jung, \& Berson, 2003).

Furthermore, when employees believe they are treated fairly, they tend to trust the system and the leaders who implement decisions (Brockner \& Siegel, 1995; Burke et al., 2007; Vanhala, Puumalainen, \& Blomqvist, 2011). This study, thus, argues that brand-specific TRL will enhance employees' trust in leader as well as in corporate brand. We suggest, however, that the effect of brand-specific TRL is weaker than its TFL counterpart. Hence, the following hypotheses are proposed: 
H2: Brand-specific TRL positively influence employee trust in (a) leader and (b) corporate brand; the hypothesized effects are smaller than those for brand-specific TFL.

There is agreement in the literature that trust in a leader enhances trust in the corporate brand to which the leader is affiliated (e.g. Brockner, Siegel, Daly, Tyler, \& Martin, 1997; Martinez \& Dorfman, 1998; Perry \& Mankin, 2007). Empirical research also finds a hierarchical relationship of trust, positing that trust starts at the inter-personal level (e.g. Mayer, Davis, \& Schoorman, 1995; Strong \& Weber, 1998). Hence, when the trustees, i.e. leaders, are highly visible, they are able to imprint personal trustworthiness on the corporate brand; at the impersonal level. Stated more formally:

H3: Trust in leader positively influences trust in corporate brand.

\section{Relationships between trust and brand identification}

Trust is defined as the willingness to be vulnerable to another party, when that party (e.g. leaders and corporate brand) cannot be controlled or monitored (Mayer \& Gavin, 2005; Rousseau, Sitkin, Burt, \& Camerer, 1998). When trust exists, employees become dependent on their trustee and demonstrate concern about the trustee's welfare (e.g. McKnight, Cummings, \& Chernavy, 1998).

Derived from social identity theory (Ashforth \& Mael, 1989), employees who identify with the corporate brand, tend to perceive their fate as intertwined with it. They define themselves by the same attributes that define the corporate brand, thus striving to maintain brand identity that is shared. Thus, identified employees are likely to share the same values as the corporate brand, enabling them to be engaged with behaviours that support brand identity. Furthermore, when employees believe in the honesty and integrity of a leader, they believe 
the accuracy of information received from that individual (Avolio, Gardner, Walumbwa, Luthans, \& May, 2004; Dirks \& Ferrin, 2002). Therefore, they are likely to be motivated by, and commit to, corporate brand goals articulated and communicated by the leader. This suggests the link between trust and the social identity concept.

Studies have documented the effects of trust on employees' identification with the organisation (e.g. Dirks and Ferrin, 2001; Ho, Kuo, \& Lin, 2012; Pillai et al., 1999). For example, Dirks and Ferrin (2001) provide empirical evidence that supports a link between trust and identification. They posit that when trust exists, employees are motivated to engage in behaviours that help them acquire rewards and achieve organisational goals. Indeed, over time, trust evolves into what has been termed identification (Lewicki and Bunker, 1996), suggesting employee emotional engagement with the leader or corporate brand. Hence, the following hypothesis is proposed:

H4: (a) Trust in leader and (b) trust in corporate brand positively influence brand identification.

Additionally, a study by Dirks \& Ferrin (2001) suggests that impersonal trust exerts a stronger impact on employees' identification than trust in leader; corroborating the work of Pillai et al. (1999). Indeed, trust in corporate brand reflects acceptance of goals and values, and a strong desire to identify with the corporate brand (Kramer, 1993; Perry and Mankin, 2007). Both trust in, and identification with, the corporate brand are considered institutionallevel commodities. Therefore, this study argues that trust in corporate brand exerts more impact on brand identification than trust in leader. 
H5: The impact of trust in leader on brand identification is smaller than the impact of trust in corporate brand on brand identification.

Based on social identity theory, highly identified individuals are more likely to behave in ways that are aligned with corporate brand values and interests (Dutton, Dukerich, \& Harquail, 1994). The effects of brand identification on employee brand-supporting behaviours are well documented (e.g. Punjaisri, Evanschitzky, \& Wilson, 2009). Morhart et al. (2009) indicate that when employees accept and adopt brand values, in-role performance and other positive brand-supporting behaviours are enhanced. Indeed, other empirical studies in this area concur that identification leads to better performance at the team level (e.g. Lembke and Wilson, 1998) and at the organisational level (e.g. van Dick and Wagner, 2002). Additionally, Hughes \& Ahearne (2010) support that when salespeople identify with the brand they expend more effort, leading to better brand performance.

Within a service recovery context, Ashill, Carruthers, \& Krisjanous (2005) suggest that identification at the organisational level has a positive effect on employees' service recovery performance. Hence, we argue that employees that identify with corporate brand expend effort to recover service failures within the remit of their corporate brand values.

H6: Brand identification positively influences service recovery performance.

Previous studies indicate the effects of trust on employees' behavioural outcomes, including in-role performance and organisational citizenship behaviours (Mayer \& Gavin, 2005; Pillai et al., 1999; Schaubroeck, Lam, \& Peng, 2011). Dirks (2000), identifies a strong and significant correlation between trust in leader and team performance. Hence, when 
employees trust their leader, they are willing to carry out tasks and strategies set by the leader, and work towards a common team goal.

However, Dirks and Ferrin (2001) observed that trust may not affect behavioural outcomes directly. Their study clarifies that trust has a small, but significant relationship with job performance, but a substantial impact on attitudinal outcomes. As such, we argue that brand identification mediates the relationship between trust in leader and service recovery performance. We therefore propose:

H7: Brand identification mediates the link between (a) trust in leader and service recovery performance, and (b) trust in corporate brand and service recovery performance

\section{Leadership effects on service recovery performance}

Studies from the organisational management literature (e.g. Pillai et al., 1999; Podsakoff, MacKenzie, \& Bommer, 1996; Schaubroeck, Lam, \& Peng, 2011) provide evidence to support the positive influence of TFL and TRL on employee performance. However, these studies consider team performance as outcome as opposed to individual employee performance (de Jong, de Ruyter, \& Lemmink, 2005; Lepine, Piccolo, Jackson, Mathieu, \& Saul, 2008). Findings generally show that TFL's effects on team performance are stronger than TRL's effects (MacKenzie, Podsakoff, \& Rich, 2001).

Teams in the management literature typically refer to groups of organisational employees with different skills and talents, who work towards a common purpose or goal (Lee, Cheng, Yeung, \& Lai, 2011). This study logically extends 'team' towards 'corporate brand', reflecting employees within the corporate brand, that work collectively towards protecting corporate brand values central to brand identity; even in the time of service failure. 
The only study from the branding literature so far (Morhart et al., 2009) has provided evidence for the effects of brand-specific TFL and TRL on employees' brand-supporting behaviours, which have positive effects on their in-role and extra-role performance. Still, the authors consider more general brand-supporting behaviours. Our study extends and clarifies the impact of leadership on one specific brand supporting behaviour: service recovery performance.

Within the services marketing literature, there is a dearth of research that has explored the role of leadership on employees' service delivery performance. In line with Liao and Chuang (2007), Clark, Hartline, \& Jones (2009) identify characteristics of brand-specific TFL that affect employees' service quality. Similarly, Lin (2011) highlights the positive and direct effect of TFL characteristics on employees' service recovery performance.

Although studies in other domains of research have investigated the effects of TFL and TRL, it is apparent that the service literature is yet to develop theory regarding the effects of brand-specific TFL and TRL on important services outcomes. However, based on studies from the organisational management literature that suggest a positive and direct effect of leadership on important employee outcomes, we posit:

H8: (a) Brand specific TFL and (b) Brand specific TRL positively influence service recovery performance.

Figure 2 shows the conceptual model underlying this research. 
Figure 2: Conceptual Model

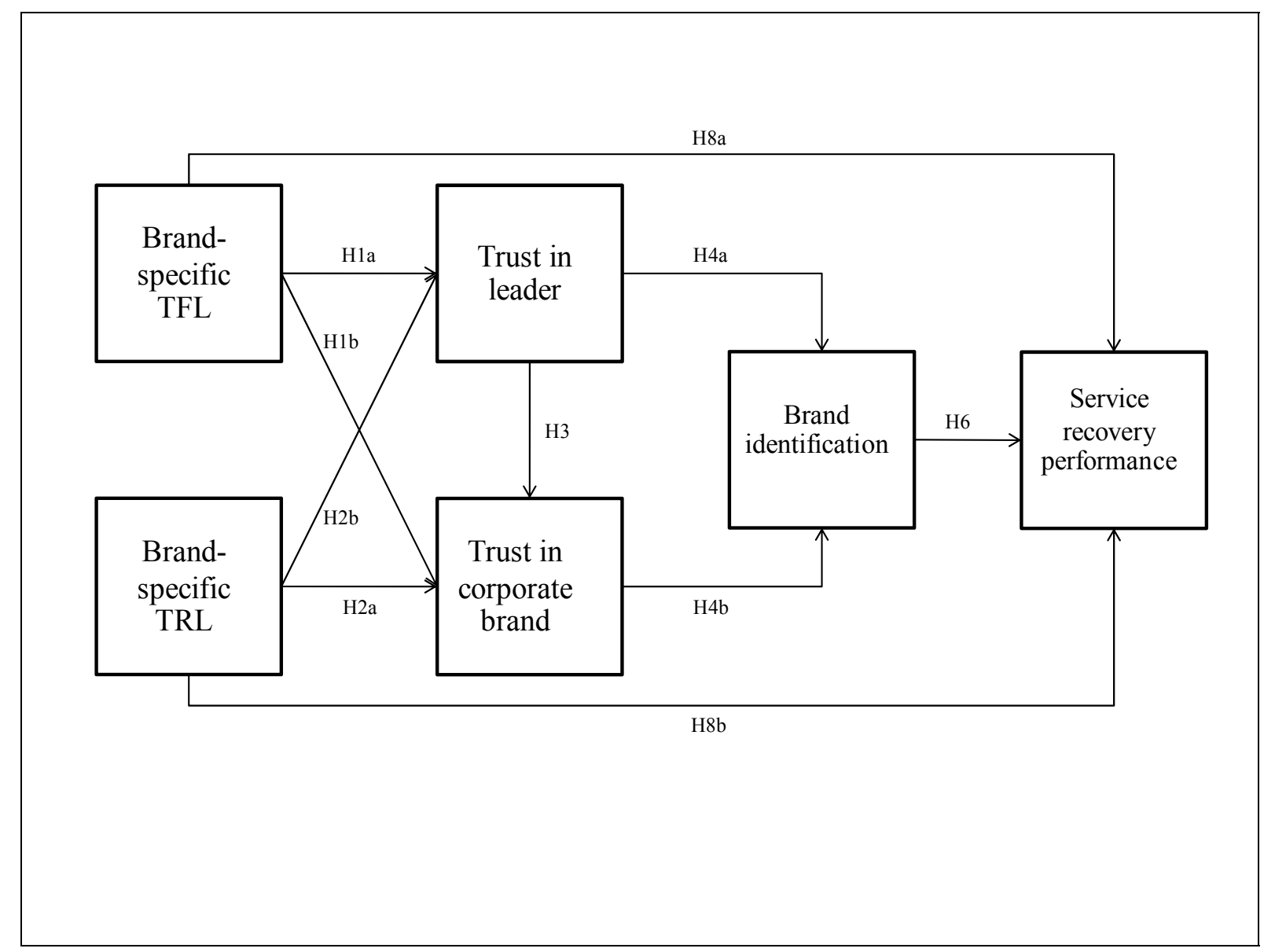




\section{Research methodology}

Data collection and sample

To test the conceptual model, a survey was conducted with customer contact employees of a multi-branch retail bank. Participants were randomly sampled from 15 branches of a reputable corporate bank in Thailand. The participating bank was deemed appropriate as it demonstrates an attempt to "living the brand promise", thereby striving to convert dissatisfied customers to the satisfied ones.

312 questionnaires were distributed to 15 sampled branches across the capital city and other main metropolitan areas for a good representation of the overall population. 246 questionnaires were returned and usable, for a response rate of $79 \%$. The high response rate is due to the interest of senior management in this research.

\section{Measure development and assessment}

A preliminary interview with senior management was conducted to help the authors gain insights into its corporate brand values and service recovery standards. These insights were useful to adapt existing measure from the literature to the specific context of the bank-setting.

The 20 items measuring brand-specific TFL were adopted from the study of Morhart et al. (2009) who adapted their measurement from the multifactor leadership questionnaire form 5X (MLQ: Avolio \& Bass, 2004). This study used homogeneous item parcelling, which is recommended by Coffman \& MacCallum (2005), to model brand-specific TFL as a singlefactor construct with five indicators (one parcel per dimension).

The 8-item brand-specific TRL scale was also adopted from Morhart et al. (2009) who adapted it from the MLQ form $8 Y$ of Bass \& Avolio (1993). Again, homogeneous item parcelling was employed to model the scale as a single-factor construct with two-indicator (one per dimension). 
The 7-item trust in the leader (TL) (e.g. Mayer \& Davis, 1999; Mayer \& Gavin, 2005; Schoorman \& Ballinger cited in Schoorman, Mayer, \& Davis, 2007), the 5-item trust in corporate brand (TCB) (e.g. Hess \& Story, 2005; Vanhala et al., 2011), the 8-item brand identification scale (e.g. Mael \& Ashforth, 1992; Shamir, Zakay, \& Popper, 1998; Punjaisri et al., 2009) and the 12-item scale measuring service recovery performance (SRP) (Ashill et al., 2008; Lin, 2011) were adapted from previous studies, complemented with insights from the preliminary interview with senior management.

All constructs have been measured with reflective measurement models, suggesting that the latent constructs cause the measured variables (Hair, Black, Babin, Anderson, \& Tatham, 2006). All items are measured on 5-point Likert scales ranging from 'strongly disagree' to 'strongly agree'. To assess the validity of the scales, a confirmatory factor analysis (CFA) was performed, leading to some item-deletions. Overall reliability and validity of the measurement instrument is good: critical ration $(\mathrm{CR})$ ranges from 0.81 to 0.95 ; average variance extracted (AVE) is between 0.52 and 0.72 ; discriminant validity was satisfied as none of the squared correlations between pairs of constructs exceeded AVE of the two constructs (Fornell and Larcker, 1981).

Appendix 1 provides items as well as psychometric properties of the measures. Table 1 provides the correlation matrix of all constructs studied. 
Table 1: Correlation Matrix of Studied Constructs

Correlations

Brand-specific transformational leader

(TFL)

Brand-specific transactional leader (TRL) $\quad 0.830 \quad 1$

Trust in leader (TL)

$0.421 \quad 0.349 \quad 1$

Trust in corporate brand (TCB)

$\begin{array}{llll}0.460 & 0.436 & 0.359 & 1\end{array}$

Brand identification (BI)

$\begin{array}{lllll}0.509 & 0.383 & 0.330 & 0.627 & 1\end{array}$

Service recovery performance (SRP)

$0.447 \quad 0.362$

$0.382 \quad 0.309$

$0.521 \quad 1$ 


\section{Results}

To test the conceptual model and its hypotheses, the authors used structural equation modelling (SEM). The resulting overall fit measures indicate that the hypothesised model is a good representation of the empirical data: $\chi^{2}(394)=836.776, p=.000 ; \mathrm{CFI}=.917 ; \mathrm{TLI}=$ $.909 ; \mathrm{RMSEA}=.068 ; \mathrm{AIC}=978.776$.

Based on the hypothesised model, H2a-b and H8b were rejected as brand-specific TRL was found not to influence trust in leader (TL) and corporate brand (TCB), nor service recovery performance (SRP). The links with regard to TL $(\beta=-0.03)$ and to $\mathrm{TCB}(\beta=0.17)$ were statistically non-significant $(p>.05)$. Similarly, the link between brand-specific TRL and SRP was found none-significant $(\beta=0.01, p>.05)$.

With regards brand-specific TFL, results suggest that it has a positive influence on TL ( $\beta=$ $0.432, p<.05)$ and TCB $(\beta=0.298, p<.1)$. Therefore, H1a and H1b are supported. The results also lend support to $\mathrm{H} 3$, indicating that TL has a positive effect on TCB. H4a-b and H5 were also supported; the results suggest that both TL $(\beta=0.215, p<.05)$ and TCB ( $\beta$ $=0.619, p<.001)$ exert a positive effect on brand identification $(\mathrm{BI})$; and that the effect of TL on $\mathrm{BI}$ is significantly smaller than TCB on BI, as indicated by a significant improve in chisquare when moving from a restricted model (the two paths are constrained to be equal) to an unrestricted on $\left(\Delta \chi^{2}(1)=5.857, \mathrm{p}<.05\right)$.

In turn, BI has a positive influence on $\operatorname{SRP}(0.309, p<.001)$. H8a is also supported as the results suggest that brand-specific TFL has a positive influence on SRP, albeit marginal ( $\beta=$ $0.250, p<.1)$. The indirect effect of brand-specific TFL on SRP was investigated and was found significant $(\beta=0.161, p<.05)$. Therefore, the results suggest that brand-specific TFL 
directly and indirectly influences SRP. Table 2 presents the path coefficients of the hypothesised model. ${ }^{2}$

2 We cross-validated findings using HLM as the 246 observations are nested in 15 branches. Results however reveal very low intraclass correlations: on average about $5 \%$ of variation lies between the 15 branches whereas $95 \%$ lies between individual employees. Moreover, HLM results are fully consistent with those obtained with SEM, with the exception of the relationship between brand-specific TRL and employees' $\mathrm{TCB}$, which was found marginally significant $(\beta=0.224, p<.1)$. 
Table 2: Path Coefficients of the Hypothesised Model

\begin{tabular}{llc}
\hline Path & $\begin{array}{c}\text { Conceptual } \\
\text { Model }\end{array}$ & Hypothesis \\
\hline Brand-specific TFL $\rightarrow$ Trust in leader & $0.432^{* * *}$ & H1a \\
Brand-specific TFL $\rightarrow$ Trust in corporate brand & $0.298^{*}$ & $\mathrm{H} 1 \mathrm{~b}$ \\
Brand-specific TRL $\rightarrow$ Trust in leader & -0.030 & $\mathrm{H} 2 \mathrm{a}$ \\
Brand-specific TRL $\rightarrow$ Trust in corporate brand & 0.176 & $\mathrm{H} 2 \mathrm{~b}$ \\
Trust in leader $\rightarrow$ Trust in corporate brand & $0.246^{* *}$ & $\mathrm{H} 3$ \\
Trust in leader $\rightarrow$ Brand identification & $0.215^{* *}$ & $\mathrm{H} 4 \mathrm{a}$ \\
Trust in corporate brand $\rightarrow$ Brand identification & $0.619^{* * *}$ & $\mathrm{H} 4 \mathrm{~b}$ \\
Brand identification $\rightarrow$ Service recovery performance & $0.309^{* * *}$ & $\mathrm{H} 6$ \\
Brand-specific TFL $\rightarrow$ Service recovery performance & $0.250^{*}$ & $\mathrm{H} 8 \mathrm{a}$ \\
Brand-specific TRL $\rightarrow$ Service recovery performance & 0.005 & $\mathrm{H} 8 \mathrm{~b}$ \\
\hline
\end{tabular}

Note: *Significant at 0.1 level, $* *$ Significant at 0.05 level, $* * *$ Significant at 0.01 level 
To formally test the mediating effect of BI on the TL-SRP- (H7a) and the TCB-SRPrelationships (H7b), the authors followed Baron and Kenny's (1986) procedure. Testing step 1 and 2 were satisfied; TL was found to have a significant relationship with SRP $(\beta=0.240$, $p<.05)$ when BI was not included in the model. When BI included, the results reveal that the link between TL and SRP remains significant, suggesting partial mediation; the total $(\beta=$ 0.313), indirect $(\beta=0.095)$, and direct $(\beta=0.218)$ effects of TL on SRP were all significant at $p<.05$. Therefore, $\mathrm{H} 7 \mathrm{a}$ is partially supported. On contrary, BI was not found to mediate the TCB-SRP-relationship. When testing the effects of TCB on SRP without BI, the relationship was found none-significant $(\beta=0.076, p>.1)$. Therefore, $\mathrm{H} 7 \mathrm{~b}$ is rejected. ${ }^{3}$

\section{Discussion}

Key findings and theoretical implications

Very little theory development has occurred regarding the important influence of leadership styles on employees' service recovery performance. Additionally, few empirical studies address the mediating influence of employee brand identification in the relationship between employee trust and employee service recovery performance; despite citations of theoretical relevance in the service recovery literature, calls for further work in this area, and also the central importance to practice (Schaubroeck et al., 2011). Our study presents insights into this theoretical gap, through a novel conceptualisation of the concepts of interest and empirical testing of hypothesised relationships.

Our findings suggest that in service recovery settings, brand specific TFL is of primary importance. Indeed, brand specific TFL impacts directly, positively and significantly on employee service recovery performance, employee trust in leader and employee trust in corporate brand. This is distinct from brand specific TRL, that does not have any significant

We also employed the Satorra-Bentler scaled chi-square statistic to assess mediation (2001) When added the direct effects of TLM and TCB on SRP, the model fit significantly improved $(\Delta \chi 2(2)=7.51, p<.05)$. These results are in line with those obtained through the traditional Barron \& Kenny procedure. 
impact on employee service recovery, employee trust in leader or employee trust in corporate brand.

Additionally, we find that employee trust in leader and corporate brand has a significant, direct and positive impact on employee brand identification. In line with existing theory, employee brand identification was found to have a direct, positive and significant impact on employee service recovery. These important theoretical findings are discussed in more depth below.

The results emphasise the importance of brand specific TFL in service recovery settings, supporting previous work in this area (Pillai et al., 1999). TFL apparently motivates followers 'by fostering a climate of trust and inducing followers to transcend self-interest for the sake of the organisation' (Pillai et al., 1999: 898). Hence, through behaviours such as rolemodelling and attempts to inspire involvement with the corporate brand, brand-specific transformational leadership may increase both employee trust in leader and also employee trust in corporate brand; additionally service recovery performance is enhanced. As such, employee performance, even during service recovery relies on overall perceptions towards leaders.

Brand-specific TRL had no significant effect on employee service recovery performance, employee trust in leader or trust in corporate brand. These findings are in line with Bycio, Hackett, \& Allen (1995) and Pillai et al. (1999) who found no relationships between TRL and trust in leader and job performance.

It is possible that the non-significant findings in our study can be explained by the country in which data was collected. Indeed, empirical evidence suggests that leadership style effectiveness is dependent on context and as such may influence results (Ling, Simsek, Lubatkin, \&Veiga, 2008). Our study was conducted in Thailand, where collectivism is dominant (Hofstede, 1983; Hofstede \& Bond, 1988). Here, employees are likely to wish to be 
regarded as part of a family or community. Hence, brand specific TFL that positively influences a sense of brand community (Morhart et al., 2009) is more likely to impact positively on employee trust in leader and corporate brand than a brand-specific TRL approach.

Our findings present insights into the relationships between employee trust in leader, employee trust in corporate brand and employee brand identification. Both levels of employee trust impact positively on employee brand identification. In particular, this study indicates that trust in corporate brand exerts a stronger impact on employee brand identification than trust in leader. This is an important finding, as brand identification is found to increase employees' service recovery performance. The key argument is that when employees identify with the brand, they perceive their fate as being intertwined with the corporate brand. They, then, become motivated to exert an effort to solve any service delivery failure that will adversely affect its corporate brand.

The opposite is true for trust in leader. When employees trust the leader they are less concerned about decisions that the leader might make. Hence, they are likely to share sensitive information including service delivery defects that enable service failures to be rectified effectively. This finding supports the work of Dirks \& Ferrin (2002), whose metaanalysis suggests that trust in the leader is more strongly related to job performance than trust in the organisation.

A direct, significant and positive relationship between employee trust in the leader and employee trust in the corporate brand was identified. Hence, trust in the leader can be leveraged towards trust in the corporate brand. While inter-personal trust between employees and the leader is of primary importance, employees, over time, may interpret the actions of leaders as the actions of the corporate brand. Therefore, in line with existing literature, leaders could imprint their personal characteristics on the corporate brand, whereby trust in 
the leader could influence trust in the corporate brand. Based on a social exchange relationship (Rousseau \& Park, 1993), brand-specific TFL will demonstrate characteristics such as charisma, inspirational motivation, and consideration thus providing a solid base from which social exchange relationships may foster trust in the leader. Then, brand-specific TFL, who is perceived by employees as representing the corporate brand, could leverage this personal social exchange relationship towards employee trust in corporate brand (Konovsky \& Pugh, 1994).

\section{Managerial implications}

This study provides practical implications for how a service firm could affect employees' service recovery performance, aligned to corporate brand values through leadership behaviours. First and foremost, leaders should consider being brand-specific when interacting with their employees. This study has indicated that transformational leaders who are brandspecific in their behaviours facilitate employees to attribute their trust towards the corporate brand. Thus, leaders are encouraged to constantly articulate the brand vision and values to their employees and interpret them into specific behaviours expected from employees, including in an event of service failures.

Brand-specific transformational leaders should also seek to tie their actions and behaviours to the brand values at all time in order to ensure that employees perform their tasks in ways that are in line with the corporate brand values at all interactions they have with customers. Other behaviours such as living the brand, and facilitating employees to rethink their jobs from a perspective of a brand representative should also be adopted by brand-specific leaders. This will enable employees to understand their role in relation to the brand and transcend their self-interest for the corporate brand's welfare.

Furthermore, although the result of this study suggests that trust in corporate brand influences employee brand identification more than trust in leader does, the former does not 
exert an impact on service recovery performance as strong as the latter. Therefore, for leaders who wish to bring about behavioural outcomes such as service recovery performance, adopting brand-specific transformational leadership behaviours is encouraged.

However, trust in corporate brand is more prominent when an organisation wishes to have employees identifying with the corporate brand. Trust in the corporate brand may not exert an impact on service recovery performance as strong as trust in the leader. However, its impact on brand identification as found in this study could still be valuable to enable employees to recover service failure in ways that will not tarnish the corporate brand identity. This is because trust in the corporate brand enhances employees' willingness to share and possess the corporate brand values that are central to its identity.

Moreover, management who focuses on work-related outcomes should place emphasis on enhancing employees' trust in the leader, rather than trust in the corporate brand. When employees trust the leader, they are more open and willing to accept service failures and involve in actions to recover them. Although trust in the leader may have a lower impact on brand identification than trust in the corporate brand, management could influence their employees' brand identification via this route. Over time, brand-specific TFL could transcend employees' trust in the leader for the trust in the corporate brand, whereby employees' brand identification is amplified.

Finally, this study suggests that management could improve their employees' service recovery performance directly by embracing the transformational characteristics of brandspecific leaders. Management are encouraged to identify the right level and conditions for transformational 'and' transactional styles. Indeed, firms, particularly the service ones, could seek to improve leader development programmes that enhance leaders' qualities and behaviours in this way. Ultimately, management should try to provide an organisational culture and climate in which brand-specific TFL can prosper. 


\section{Limitations and future research directions}

It is important to view research findings in the light of limitations. The chosen sample was from a single organisation in one country. This is likely to restrict the generalisability of the findings. This study included employees from different departments where there are customer-employee interface. According to Morgeson, DeRue, \& Karam (2010), teams may have different unique needs, which influence the role of the team leadership. Therefore, customer-facing staff may have some characteristics that differ from those working in other departments, thereby influencing relationships between the variables.

Furthermore, this study highlights the role of brand-oriented leaders. The organisation that was sampled is a reputable corporate brand and demonstrates an attempt to deliver on its brand promise that encapsulates the core brand values and brand identity. As such, brandspecific leaders could be more readily accepted in the company. It is interesting to understand whether and how brand-oriented leaders would be appreciated in companies whose brands are not as strong and/or prominent. Under this light, future studies could extend our study by including samples from diverse departments from different organisations, possibly customerfacing teams.

As this study was cross-sectional in nature, we have to be cautious about possible time-lag effects and causal inferences. Therefore, further studies should apply a longitudinal approach to assess the temporal interplay between the key variables studied. Quite possibly, the effect of trust on brand supporting behaviours becomes more pronounced over time.

Furthermore, more studies are encouraged to help establish the relationship between trust in leader and trust in corporate brand; for example, future research could determine whether trust in management mediates the link between leadership behaviours and employee trust in corporate brand, and what other variables could be involved. 
Finally, this study has indicated that a total effect of brand-specific TFL and TRL was mediated by different variables. However, they were not completely independent. More precise and distinct identification of causal paths should be carried out by more studies in order to develop models of leadership and service recovery performance.

\section{Conclusion}

Turbulent markets challenge organisations to constantly assess and reassess their market offers, in search of a competitive advantage. Service-based differentiation between competitors is often seen as a more sustainable and profitable approach to long-term business survival, with more and more businesses incorporating service-based offerings into their portfolios.

However, it is unrealistic to believe that mistakes will not occur, and some degree of service failure will befall any service-based organisation, whether experienced in this area or not. Evidence suggest that service failure in itself can, and will, be forgiven by customers, but service recovery performance, has a significant impact on a range of financial and nonfinancial indices; both in the long and short-terms.

While empirically grounded advice is available to practitioners regarding service recovery, little theory development has occurred to address leadership issues relating to this important driver of competitive success. Our findings provide much needed theoretical development and practical insights. The central role of brand-specific transformational leadership is highlighted and its importance to service recovery performance, mediated by employee trust and brand identification is emphasised. 


\section{References}

Ashforth, B. \& Mael, F. (1989). Social identity theory and the organization. Academy of Management Review, 14, 20-39. doi: 10.5465/AMR.1989.4278999

Ashill, N.J., Rod, M., \& Carruthers, J. (2008). The effect of management commitment to service quality on frontline employees' job attitudes, turnover intentions and service recovery performance in a new public management context. Journal of Strategic Marketing, 16, 437-462. doi: 10.1080/09652540802480944

Atkinson, S. \& Butcher, D. (2003). Trust in managerial relationships. Journal of Managerial Psychology, 18, 282-304. doi: 10.1108/02683940310473064

Avolio, B.J. \& Bass, B.M. (2004). Multifactor leadership questionnaire: Manual and sampler set ( $3^{\text {rd }}$ ed.). Menlo Park, CA: Mind Garden.

Avolio, B.J., Gardner, W.L., Walumbwa, F.O., Luthans, F., \& May, D.R. (2004). Unlocking the mask: A look at the process by which authentic leaders impact follower attitudes and behaviors. The Leadership Quarterly, 15, 801-823. doi: 10.1016/j.leaqua.2004.09.003

Baron, R.M. \& Kenny, D.A. (1986). The moderator-mediator variable distinction in social psychological research: Conceptual, strategic, and statistical considerations. Journal of Personality and Social Psychology, 51, 1173-1182. doi: 10.1037/0022-3514.51.6.1173

Bass, B.M. (1985). Leadership and performance beyond expectations. New York, NY: The Free Press.

Bass, B.M. \& Avolio, B.J. (1993). Transformational leadership: A response to critiques. In M. M. Chemers \& R. Ayman (Eds.), Leadership theory and research: Perspectives and directions (pp. 21-35). San Diego, CA: Academic Press, San Diego.

Bass, B.M., Avolio, B.J., Jung, D.I., \& Berson, Y. (2003). Predicting unit performance by assessing transformational and transactional leadership. Journal of Applied Psychology, 88, 207-18. doi: 10.1037/0021-9010.88.2.207 
Baumgarth, C. (2008). Brand orientation of museums: model and empirical results. International Journal of Arts Management, 11(3), 30-45.

Bell, C.R. \& Zemke, R.E. (1987). Service breakdown: The road to recovery. Management Review, 76(10), 32-35.

Berry, L.L. (2000). Cultivating service brand equity. Journal of the Academy of Marketing Science, 28, 128-137. doi: 10.1177/0092070300281012

Berry, L.L. \& Lampo, S.S. (2004). Branding labour-intensive services. Business Strategy Review, 15(1), 18-25. doi: 10.1111/j.0955-6419.2004.00296.x

Berry, L.L., Lefkowith, E.F., \& Clark, T. (1988). In services, What's in the name?. Harvard Business Review, 66(5), 28-30. Retrieved from http://www.hbr.org

Boshoff, C.R. (1997). An experimental study of service recovery options. International Journal of Service Industry Management, 8(2), 110-130. Retrieved from http://www.emeraldinsight.com

Boshoff, C.R., Allen, J. (2000). The influence of selected antecedents on frontline staff's perceptions of service recovery performance. International Journal of Service Industry Management, 11(1), 63-90. doi: 10.1108/09564230010310295

Brockner, J. \& Siegel, P. (1995). Understanding the interaction between procedural and distributive justice: The role of trust. In R.M. Kramer \& T.R. Tyler (Eds.), Trust in organizations: Frontiers of theory and research (pp. 391-413). Thousand Oaks, CA: Sage.

Brockner, J., Siegel, P.A., Daly, J.P., Tyler, T., \& Martin, C. (1997). When trust matters: The moderating effect of outcome favorability, Administrative Science Quarterly, 42, 558-583. Retrieved from http://www.johnson.cornell.edu/publications/asq/

Brower, H.H., Schoorman, F.D., \& Tan, H.H. (2000). A model of relational leadership: The integration of trust and leader-member exchange. Leadership Quarterly, 11, 227-50. Retrieved from http://www.jaipress.com 
Burke, C.S., Sims, D.E., Lazzara, E.H., \& Salas, E. (2007). Trust in leadership: A multi-level review and integration. The Leadership Quarterly, 19, 606-632. Retrieved from http://www.jaipress.com

Bycio, P., Hackett, R., \& Allen, J. (1995). Further assessments of Bass's (1985) conceptualization of transactional and transformational leadership. Journal of Applied Psychology, 80, 468-478. Retrieved from http://www.apa.org/journals/apl

Coffman, D.L. \& MacCallum, R.C. (2005). Using parcel to convert path analysis models into latent variable models. Multivariate Behavioral Research, 40, 235-259. doi: $10.1207 / \mathrm{s} 15327906 \mathrm{mbr} 4002 \_4$

Colquitt, J., Conlon, E., Wesson, M., Porter, C., \& Ng, K. (2001). Justice at the millennium: A meta-analytic review of 25 years of organizational justice. Journal of Applied Psychology, 86, 425-445. doi: 10.1037/0021-9010.86.3.425

De Jong, A., de Ruyter, K., \& Lemmink, J. (2005). Service climate in self-managing teams: mapping the linkage of team member perceptions and service performance outcomes in a business-to-business-setting. Journal of Management Studies, 42, 1593-1620. doi: 10.1111/j.1467-6486.2005.00558.x

De Matos, Celso A., Henrique, Jorge L., and Carlos A.V. Rossi (2007). Service Recovery Paradox: A Meta-Analysis. Journal of Service Research, 10(1), 60-77. doi: $10.1177 / 1094670507303012$

Dirks, K.T. (2000). Trust in leadership and team performance: Evidence from NCAA basketball. Journal of Applied Psychology, 85, 1004-1012. doi: 10.1037/00219010.85 .6 .100

Dirks, K.T. \& Ferrin, D.L. (2001). The role of trust in organizational settings, Organization Science, 12, 450-467. doi: 10.1287/orsc.12.4.450.10640 
Dirks, K.T. \& Ferrin, D. L. (2002). Trust in leadership: Meta-analytic findings and implications for research and practice. Journal of Applied Psychology, 87, 611-628. doi: $10.1037 / / 0021-9010.87 .4 .611$

Dutton, J.E., Dukerich, J.M., \& Harquail, C.V. (1994). Organizational images and member identification. Administrative Science Quarterly, 39, 239-263. Retrieved from: http://www.johnson.cornell.edu/publications/asq/

Evanschitzky, H., Brock, C., \& Blut, M. (2011). Will You Tolerate this? The Impact of Affective Commitment on Complaint Intention and Post-Recovery Behavior. Journal of Service Research, 14 (4), 410-425. doi: 10.1177/1094670511423956

Ewing, M.T. and Napoli, J. (2005). Developing and validating a multidimensional non-profit brand orientation scale. Journal of Business Research, 58, 841-853. doi: 10.1016/j.jbusres.2003.09.012

Fornell, C. and Larcker D.F. (1981). Evaluating structural equation models with unobservable variables and measurement error. Journal of Marketing Research, 18, 39-50. Retrieved from http://www.ama.org/

Gillespie, N.A. \& Mann, L. (2004). Transformational leadership and shared values: The building blocks of trust. Journal of Managerial Psychology, 19, 588-607. doi: $10.1108 / 02683940410551507$

Hair, J.F., Jr., Black, W.C., Babin, B.J., Anderson, R.E., \& Tatham, R.L. (2006). Multivariate Data Analysis (6 ${ }^{\text {th }}$ ed.). Upper Saddle River, NJ: Prentice Hall.

Hart, C.W.L., Heskett, J.L., \& Sasser, W.E., Jr. (1990). The profitable art of service recovery, Harvard Business Review, 68(4), 148-156. Retrieved from http://www.hbr.org

Heskett, J., Sasser, W.E., Jr., \& Schlesinger, L. (1997). The service profit chain: How leading companies link profit and growth to loyalty, satisfaction, and value. New York, NY: The Free Press. 
Hess, J. \& Story, J. (2005). Trust-based commitment: Multidimensional consumer-brand relationships. The Journal of Consumer Marketing, 22, 313-322. doi:

$10.1108 / 07363760510623902$

Ho, L-A., Kuo, T-H., \& Lin, B. (2012). How social identification and trust influence organizational online knowledge sharing. Internet Research, 22, 4-28. doi: $10.1108 / 10662241211199942$

Hofstede, G. (1983). The cultural relativity of organizational practices and theories. Journal of International Business Studies, 14(23), 75-89. Retrieved from http://www.jstor.org/

Hofstede, G. \& Bond, M.H. (1988). The Confucius connection from cultural roots to economic growth. Organizational Dynamics, 16(4), 5-21. Retrieved from http://www.elsevier.com/locate/orgdyn

Hughes, D.E. \& Ahearne, M. (2010). Energizing the reseller's sales force: The power of brand identification. Journal of Marketing, 74(4), 81-96. doi: 10.1509/jmkg.74.4.81

Johnston, R. (1995). Service failure and recovery: Impact, attributes and process. Advances in Services Marketing and Management: Research and Practice, 4, 211-228.

Johnston, R. and Fern, A. (1999). Service recovery strategies for single and double deviation scenarios. The Service Industries Journal, 19(2), 69-82. Retrieved from http://www.tandf.co.uk/journals/titles/02642069.asp

Jung, D. \& Avolio, B. (2000). Opening the black box: An experimental investigation of the mediating effects of trust and value congruence on transformational and transactional leadership. Journal of Organizational Behavior, 21, 949-964. doi: 10.1002/10991379(200012)21:8<949::AID-JOB64>3.0.CO;2-F

Kelley, S.W., Hoffman, K.D., \& Davis, M.A. (1993). A typology of retail failures and recoveries. Journal of Retailing, 69, 429-452. doi: 10/1016/0022-4539(93)90016-C 
Kramer, R.M. (1993) Cooperation and organizational identification. In K. Murnighan (Ed.), Social psychology in organizations: Advances in theory and research (pp. 244-268), Englewood Cliffs, NJ: Prentice Hall.

Konovsky, M.A. \& Pugh, S.D. (1994). Citizenship behavior and social exchange. Academy Management Journal, 37, 656-669. doi: 10.2307/256704

Lee, P.K.C., Cheng, T.C.E., Yeung, A.C.L., \& Lai, K-H. (2011). An empirical study of transformational leadership, team performance and service quality in retail banks. The International Journal of Management Science OMEGA, 39, 690-701. doi: 10.1016/j.omega.2011.02.001

Lembke, S. \& Wilson, M.G. (1998). Putting the 'team' into teamwork: Alternative theoretical contributions for contemporary management practice. Human Relations, 57, 927-944.

Lepine, J.A., Piccolo, R.F., Jackson, C.L., Mathieu, J.E., \& Saul, J.R. (2008). Meta-analysis of teamwork processes: tests of a multidimensional model and relationships with team effectiveness criteria. Personnel Psychology, 61, 273-307. doi: 10.1111/j.1744$6570.2008 .00114 . x$

Lewicki, R. \& Bunker, B. (1996). Developing and maintaining trust in work relationships. In R.M. Kramer \& T.R. Tyler (Eds.), Trust in organizations: Frontiers of theory and research (pp. 114-139). Thousand Oaks, CA: Sage.

Liao, H. (2007). Do it right this time: The role of employee service recovery performance in customer-perceived justice and customer loyalty after service failures. Journal of Applied Psychology, 92, 475-489. doi: 10.1037/0021-9010.92.2.475

Liao, H. \& Chuang, A. (2007). Transforming service employees and climate: A multilevel, multi-source and examination of transformational leadership in building long-term service relationships. Journal of Applied Psychology, 92, 1006-1019. doi: 10.1037/00219010.92.4.1006 
Lin, W-B. (2011). Factors affecting the effects of service recovery from an integrated point of view. Total Quality Management, 22, 443-459. doi: 10.1080/14783363.2010.545553

Ling, Y., Simsek, Z., Lubatkin, M.H., Veiga, J.F. (2008). The impact of transformational CEOs on the performance of small-to medium-sized firms: Does organisational context matter?. Journal of Applied Psychology, 93, 923-934. doi: 10.1037/0021-9010.93.4.923.

Liou, T.K. (1995). Understanding employee commitment in the public organisation: A study of the juvenile detention centre. International Journal of Public Administration, 18, 12691295. doi: 10.1080/01900699508525052

MacKenzie, S.B., Podsakoff, P.M., \& Rich, G. A. (2001). Transformational and transactional leadership and salesperson performance. Journal of the Academy of Marketing Science Journal, 29, 115-134. Retrieved from http://www.springer.com/business/journal/11747

Mael, F.A. \& Ashforth, B.E. (1992). Alumni and their alma mater: A partial field test of the reformulated model of organizational identification. Journal of Organizational Behavior, 13, 103-123. Retrieved from http://www.jstor.org/stable/2488176

Mael, F.A. and Ashforth, B.E. (1995). Loyal from one: Biodata, organization, and turnover among newcomers. Personnel Psychology, 48, 309-333. Retrieved from http://www.wiley.com/WileyCDA/

Magnini, V., Ford, J., Markowski, E., \& Honeycutt, E., Jr. (2007). The service recovery paradox: justifiable theory or smouldering myth. Journal of Services Marketing, 21(3), 213-225. doi: 10.1108/08876040710746561

Martinez, S.M. \& Dorfman, P.W. (1998). The Mexican entrepreneur: An ethnographic study of the Mexican 'emprisario'. International Studies of Management and Organization, 28(2), 97. Retrieved from http://www.mesharpe.com/results1.asp?ACR=imo 
Mayer, R.C. \& Davis, J.H. (1999). The effect of the performance appraisal system on trust for management: A field quasi-experiment. Journal of Applied Psychology, 84, 123-136. Retrieved from http://www.apa.org/journals/apl

Mayer, R.C., Davis, J.H., \& Schoorman, F.D. (1995). An integrative model of organizational trust. Academy of Management Review, 20, 709-734. doi:

10.5465/AMR.1995.9508080335

Mayer, R.C. \& Gavin, M.B. (2005). Trust in management and performance: who minds the shop while the employees watch the boss?. Academy of Management Journal, 48, 874888. doi: 10.5465/AMJ.2005.18803928

Mayer, D., Kuenzi, M., Greenbaum, R., Bardes, M., \& Salvador, R. (2009). How low does ethical leadership flow? Test of a trickle-down model. Organizational Behavior and Human Decision Process, 108, 1-13. doi: 10/1016/j.obhdp.2008.04.002

McKnight, D.H., Cummings, L.L., \& Chervany, N.L. (1998). Initial trust formation in new organizational relationships, Academy of Management Review, 23, 473-490. doi: 10.5465/AMR.1998.926622

Miles, S.J. \& Mangold, G. (2004). A Conceptualization of the employee branding process. Journal of Relationship Marketing, 3(2-3), 65-87. Retrieved from http://www.tandfonline.com/openurl?genre=journal\&eissn=1533-2675

Morhart, F.M., Herzog, W., \& Tomczak, T. (2009). Brand-specific leadership: Turning employees into brand champions. Journal of Marketing, 73(5), 122-142. Retrieved from http://www.tandfonline.com/openurl?genre=journal\&eissn=1533-2675

Morgeson, F.P., DeRue, D.S., \& Karam, E. P. (2010). Leadership in teams: A functional approach to understanding leadership structures and processes. Journal of Management, 36, 5-39. Retrieved from http://jom.sagepub.com/archive/ 
Morsing, M. \& Kristensen, J. (2001). The question of coherency in corporate branding - over time and across stakeholders. Journal of Communication Management, 6, 24-40. doi: $10.1108 / 13632540210806919$

Motowidlo, S.J. (2003). Job performance. In W.C. Borman, D.R. Ilgen, \& R.J. Klimoski (Eds.), Handbook of psychology: Industrial and organizational psychology (Vol. 12, pp. 39-53). London: Wiley.

Mullen, J.E. \& Kelloway, E. K. (2009). Safety leadership: A longitudinal study of the effects of transformational leadership on safety outcomes. Journal of Occupational and Organizational Psychology, 82, 253-272. Retrieved from http://www.wiley.com/WileyCDA/

Perry, R.W. and Mankin, L.D. (2007). Organizational trust: Trust in chief executive and work satisfaction. Public Personnel Management, 36, 165-179. Retrieved from http://www.ipma-hr.org/

Pillai, R., Schriesheim, C.A. and Williams, E. (1999). Fairness perceptions and trust as mediators for transformational and transactional leadership: A two-sample study. Journal of Management, 25, 897-934. Retrieved from http://www.sagepub.com/journal.aspx?pid=10604

Podsakoff, P.M., MacKenzie, S.B., Moorman, R.H., \& Fetter, R. (1990). Transformational leader behaviors and their effects on followers' trust in leader, satisfaction, and organizational citizenship behaviors. Leadership Quarterly, 1, 107-142. doi: $10.1016 / 1048-9843(90) 90009-7$

Podsakoff, P. M., MacKenzie, S. B., \& Bommer, W. H (1996). Transformational leader behaviors and substitutes for leadership as determinants of employee satisfaction, commitment, trust, and organizational citizenship behaviors. Journal of Management, 22 (2), 259-298. doi: 10.1016/1048-9843(90)90009-7 
Punjaisri, K., Evanschitzky, H., \& Wilson, A. (2009). Internal branding: An enabler of employees' brand-supporting behaviours, Journal of Service Management, 20, 209-226. doi: $10.1108 / 09564230910952780$

Rich, G. (1997). The sales manager as a role model: Effects on trust, job satisfaction and performance of salespeople. Journal of Academy of Marketing Science, 25, 319-328. Retrieved from http://www.springer.com/business/journal/11747

Rousseau, D.M. \& Parks, J.M. (1993). The contracts of individuals and organizations. In B. M. Sstaw \& L.L. Cummings (Eds.), Research in Organizational Behavior (Vol. 15, pp. 143). Greenwich, CT: JAI Press.

Rousseau, D.M., Sitkin, S.B., Burt, R.S., \& Camerer, C. (1998). Not so different after all: A cross-discipline view of trust, Academy of Management Review, 23, 393-404. doi: 10.5465/AMR.1998.926617

Ruiz, P., Ruiz, C., \& Martinez, R. (2011). Improving the 'leader-follower' relationship: Top manager or supervisor? The ethical leadership trickle-down effect on follower job response. Journal of Business Ethics, 99, 587-608. doi: 10.1007/s10551-010-0670-3

Satorra, A. \& Bentler, P. (2001). A scaled difference chi-square test statistic for moment structure analysis. Psychometrika, 66, 507-514. Doi: 10.1007/BF02296192

Schneider, B. \& Bowen, D.E. (1985). Employee and customer perceptions in banks: Replication and extension. Journal of Applied Psychology, 70, 432-443. doi: $10.1037 / 0021-9010.70 .3 .423$

Schneider, B., Ehrhart, M.G., Mayer, D.M., \& Satlz, J.L. (2005). Understanding organizational-customer linkages in service settings. Academy of Management Journal, 48, 1017-1032. doi: 10.5465/AMJ.2005.19573107 
Schoorman, F.D., Mayer, R.C., \& Davis, J.H. (2007). An integrative model of organizational trust: Past, present, and future. Academy of Management Review, 32, 344-354. doi: 10.5465/AMR.2007.24348410

Shamir, B. (1995). Social distance and charisma: Theoretical notes and an exploratory study. Leadership Quarterly, 6, 19-47. doi: 10.1016/1048-9843(95)90003-9

Shamir, B., Zakay, E., \& Popper, M. (1998). Correlates of charismatic leader behavior in military units: Subordinates' attitudes, unit characteristics, and superiors' appraisals performance. Academy of Management Journal, 41, 387-409. doi: 10.2307/257080

Sparks, B.A. \& McColl-Kennedy, J.R. (2001). Justice strategy options for increased customer satisfaction in a service recovery setting. Journal of Business Research, 54, 209-218. doi: $10.1016 / \mathrm{S} 0148-2963(00) 00120-\mathrm{X}$

Strong, K. \& Weber, J. (1998). The myth of the trusting culture: A global, empirical assessment. Business and Society, 37, 157-183. doi: 10.1177/000765039803700203

Urde, M. (1999). Brand orientation: A mindset for building brands into strategic resources. Journal of Marketing Management, 15, 117-133. Retrieved from http://www.tandf.co.uk/journals/titles/0267257X.asp

Vallaster, C. \& de Chernatony, L. (2005). Internationalisation of services brands: The role of leadership during the internal brand building process. Journal of Marketing Management, 21, 181-203. Retrieved from http://www.tandf.co.uk/journals/titles/0267257X.asp

Van Dick, R. \& Wagner, U. (2002). Social identification among school teachers: Dimensions, foci, and correlates. European Journal of Work \& Organizational Psychology, 11, 129149. doi: $10.1090 / 13594320143000889$

Van Knippenberg, D. \& Sleebos, E. (2006). Organizational identification versus organizational commitment: Self-definition, social exchange, and job attitudes. Journal of Organizational Behavior, 27, 571-584. doi: 10.1002/job.359. 
Vanhala, M., Puumalainen, K., \& Blomqvist, K. (2011). Impersonal trust: The development of the construct and the scale. Personnel Review, 40, 485-513. doi: $10.1108 / 00483481111133354$

Wieseke, J., Ahearne, M., Lam, S.K., \& van Dick, R. (2009). The role of leaders in internal Marketing. Journal of Marketing, 73(2), 123-145. doi: 10.1509/jmkg.73.2.123 
Appendix 1: Reliability and Validity of Construct

\begin{tabular}{|c|c|c|c|c|}
\hline Item & Factor & Loading & CR & AVE \\
\hline $\begin{array}{l}\text { Intellectual Stimulation (Parcel) } \\
\text { Inspirational Motivation (Parcel) } \\
\text { Idealised Influence (Attributes) (Parcel) } \\
\text { Idealised Influence (Behaviours) (Parcel) } \\
\text { Individual Consideration (Parcel) }\end{array}$ & TFL & $\begin{array}{l}0.761 \\
0.849 \\
0.901 \\
0.902 \\
0.806\end{array}$ & 0.926 & 0.715 \\
\hline $\begin{array}{l}\text { Management by exception active (Parcel) } \\
\text { Contingent reward (Parcel) }\end{array}$ & TRL & $\begin{array}{l}0.816 \\
0.883\end{array}$ & 0.839 & 0.723 \\
\hline $\begin{array}{l}\text { I would tell my leader about mistakes I've made on the job, } \\
\text { even if they could damage my reputation. } \\
\text { I would share my opinion about sensitive issues with my } \\
\text { leader, even if my opinion were unpopular. } \\
\text { If my leader asked why a problem happened, I would speak } \\
\text { freely, even if I were partly to blame. } \\
\text { If my leader asked me for something, I respond without } \\
\text { thinking about whether it might be held against me. }\end{array}$ & TLM & $\begin{array}{l}0.614 \\
0.656 \\
0.791 \\
0.794\end{array}$ & 0.808 & 0.516 \\
\hline $\begin{array}{l}X \text { does what it takes to make me happy in a fair manner. } \\
\text { I believe that management of X makes every effort to resolve } \\
\text { employees' problems in a well-founded manner. } \\
\text { I believe that X has resources and procedures in place that are } \\
\text { very responsive to employees' issues. } \\
\text { X is committed to keep the brand promise they made to me } \\
\text { and to customers in order to achieve the corporate brand's } \\
\text { goal. } \\
\text { I believe that my corporate brand stands behind its vision, } \\
\text { values, and identity. }\end{array}$ & TCB & $\begin{array}{l}0.687 \\
0.864 \\
0.852 \\
0.905 \\
0.790\end{array}$ & 0.912 & 0.677 \\
\hline $\begin{array}{l}\text { I am proud to tell others that I am part of this corporate brand } \\
\text { (X). } \\
\text { I feel a sense of ownership for X rather than being just an } \\
\text { employee. } \\
\text { I view the success of the brand as my own success. } \\
\mathrm{X} \text { is like a family to me. } \\
\text { All in all, I am glad to belong to X. } \\
\text { When I talk about this corporate brand, I usually say 'we' } \\
\text { rather than 'they'. } \\
\text { When someone praises X, it feels like a personal compliment. } \\
\text { Working for X is an important part of who I am. }\end{array}$ & BI & $\begin{array}{l}0.797 \\
\\
0.767 \\
0.861 \\
0.877 \\
0.885 \\
\\
0.830 \\
0.869 \\
0.834\end{array}$ & 0.951 & 0.707 \\
\hline $\begin{array}{l}\text { Considering all the things I do, I handle dissatisfied customers } \\
\text { quite well. } \\
\text { I do not mind dealing with complaining customers. } \\
\text { No customer I deal with leaves with problem unresolved. } \\
\text { Satisfying complaining customers is a great thrill to me. } \\
\text { Complaining customers I have dealt with in the past are } \\
\text { among today's most satisfied and loyal customers. } \\
\text { Considering all the things I do during service recovery, I } \\
\text { manage to stay true to X values. }\end{array}$ & SRB & $\begin{array}{l}0.766 \\
0.749 \\
0.691 \\
0.628 \\
\\
0.745\end{array}$ & 0.874 & 0.538 \\
\hline
\end{tabular}

